\title{
ROLE OF SALICYLIC ACID IN HEAT STRESS TOLERANCE IN TRI-GENOMIC Brassica napus L.
}

\author{
Muhammad Awais Ghani ${ }^{1}$, Muhammad Mehran Abbas ${ }^{1}$, Basharat Ali ${ }^{2}$, Khurram Ziaf ${ }^{1}$, \\ Muhammad Azam ${ }^{1}$, Romana Anjum ${ }^{3}$, Qumer Iqbal ${ }^{4}$, Mubashar Nadeem², \\ Anam Noor ${ }^{1}$ and Uzma Jillani ${ }^{1}$
}

\begin{abstract}
Tri-genomic Brassica napus L. was developed by the cross between Brassica napus and Brassica nigra. The crop is an important source of vegetable seed oil in Pakistan, after cotton. The low oilseed rape yield is attributed to high temperature in the production zones. Interspecific hybridization using these two species can be helpful to produce heat resistant hybrids. On the other hand, it has been found that foliar application of different plant growth regulators can be used to reduce the heat stress in Brassica. The objective of this study was to test the response of three different tri-genomic hybrids to high temperature stress at seedling stage. Seedlings were foliar sprayed with $0.13 \mathrm{mM}$ salicylic acid (SA) prior to exposure to high temperature at two true leaf stage. The plants were harvested after 30 days of sowing for growth and biochemical analysis. Plants of V38 showed the highest values for all morphological traits and biochemical activities among the three hybrids. In general, plants exposed to the temperature stress exhibited a significant decline in growth, chlorophyll content and enzyme activity. Foliar application of SA significantly improved leaf and root biomass under heat stress. Further, antioxidative enzyme activities significantly increased in response to SA either compared to control or to plants exposed to temperature stress. It is concluded that application of salicylic acid elevated activity of antioxidative enzymes and was helpful in mitigating the detrimental effects of high temperature in oil seed rape.
\end{abstract}

Additional keywords: Antioxidative enzymes, canola, high temperature, tri-genomic oilseed rape

\section{RESUMEN}

El rol del ácido salicílico en la tolerancia del estrés térmico en Brassica napus L. trigenómica

Brassica napus trigenómica fue desarrollada por el cruce entre Brassica napus y Brassica nigra. El cultivo es una fuente muy importante de aceite vegetal en Pakistán, después del algodón. El rendimiento de la canola es bajo, atribuido a las altas temperaturas en las zonas de producción. El mejoramiento de la hibridación entre las dos especies puede ser útil para producir híbridos resistentes al calor. Por otra parte, se ha encontrado que la aplicación foliar de diferentes reguladores del crecimiento pueden reducir el estrés por calor en Brassica. En el presente estudio se sometieron plántulas de tres híbridos trigenómicos a temperatura de $40^{\circ} \mathrm{C}$. Las plántulas se rociaron con ácido salicílico (AS) 0,13 mM antes de exponerlas al estrés térmico. Las plántulas se cosecharon a los 30 días después de la siembra para la determinación del crecimiento y análisis bioquímicos. Las plantas de V38 mostraron los valores más altos para todos los rasgos morfológicos y actividades bioquímicas entre los tres híbridos estudiados. En general, las plantas expuestas al estrés térmico mostraron una disminución en el crecimiento, el contenido de clorofila y la actividad enzimática. La aplicación foliar de SA mejoró significativamente la biomasa de hojas y raíces. Además, la actividad de las enzimas antioxidantes aumentó significativamente en respuesta al SA, tanto en comparación con el control como con respecto a las plantas expuestas al estrés por temperatura. Se concluye que la aplicación de ácido salicílico elevó la actividad de las enzimas antioxidantes y fue útil para mitigar los efectos perjudiciales de las altas temperaturas en la canola.

Palabras clave adicionales: Canola tri-genómica, enzimas antioxidantes, temperaturas altas

\section{INTRODUCTION}

Canola (Brassica napus L.) is a worldwide source of edible oil (Zhou, 2001; Momoh et al., 2002). Tri-genomic Brassica napus, belonging to the family Brassicaceae, was developed by the

Received: March 13, 2020

Accepted: October 11, 2020

${ }^{1}$ Institute of Horticultural Sciences, University of Agriculture, Faisalabad, Pakistan.

e-mail: awais.ghani@uaf.edu.pk (corresponding author)

${ }^{2}$ Department of Agronomy, University of Agriculture, Faisalabad, Pakistan. e-mail: basharat2018@yahoo.com

${ }^{3}$ Department of Plant Pathology, University of Agriculture, Faisalabad, Pakistan. e-mail: romana.anjum@uaf.edu.pk

${ }^{4}$ Fiblast LLC, Tuskegee, AL, USA. e-mail: iqbalqumer@fiblast.com 
cross between B. nigra and B. napus (Abbas, 2018). Canola is cultivated as a major oilseed crop in Canada, Europe, China, Australia, USA, and the Indian subcontinent. The global temperature is increasing by the emission of greenhouse gases that trap heat in the atmosphere and thus enhance the earth temperature (Porter, 2005). High temperature creates an adverse effect on environment that impairs agriculture and crop production systems as well as contributes to the geographical distribution of natural plant species such as cereals, vegetables, and oilseed rape (Mizanur, 2018).

During flowering stage, high temperature reduces seed yield in both monocotyledon and dicotyledonous plants, for example Brassica napus (Angadi et al., 2000), Solanum lycopersicum (Sato et al., 2002) and Triticum aestivum (Carlson, 1990). The different species are affected by the heat stress at the flower stage. The ambient temperature in the previous century has risen by $\sim 0.8{ }^{\circ} \mathrm{C}$ and is predicted to increase another $\sim 2$ to $4{ }^{\circ} \mathrm{C}$ by the end of this century (IPCC, 2014). Rising global temperature will affect the growth, development, and productivity of plants. Heat stress shows different responses across plant species, depending on the duration of temperature increase and the plant developmental stage when the heat stress occurred (Prasad, 2017). High temperatures during flowering and seed set can significantly reduce yield and is one of the major barriers to the global expansion of crops (Fuentes and Bhargava, 2011; Lesjak and Calderini, 2017).

The optimum temperature required for germination and seed development of Brassica is $25-33{ }^{\circ} \mathrm{C}$. High temperatures (above $33{ }^{\circ} \mathrm{C}$ ) also affect the seed pod development in Brassica which causes loss of yield (Young et al., 2004). During the high temperature, oxidative damage occurs through generation of reactive oxygen species (ROS) (Knight and Knight, 2001). Plants have developed both enzymatic and nonenzymatic detoxification systems to counteract ROS, thereby protecting cells from oxidative damage (Sairam and Tyagi, 2004). The antioxidant enzymes include peroxidase (POD), catalase (CAT), superoxide dismutase (SOD) (Wahid et al., 2007). These enzymes have been reported to improve heat stress tolerance in plants (Kubo et al., 1999). Protection against oxidative stress is an important component in determining the survival of a plant under high temperature, and antioxidant defense strength is correlated with acquisition of heat stress tolerance.

Rapid and effective measures of plant treatment are necessary, so that deterioration of crops due to high temperature can be countered successfully. Plant growth regulators are known to play an important role in plants stress tolerance (Chakrabarti and Mukherjee, 2003). Salicylic acid (SA) has been recognized as a plant hormone that plays different physiological roles in plants such as early flowering, increased uptake of nutrients, increased photosynthesis and enzyme activities (Hayat et al., 2007). Tomato seed treatment with $0.5 \mathrm{mM}$ SA have not showed any injury symptoms under stress condition (Senaratna et al., 2000). Clarke et al. (2009) suggested that SA have induced heat tolerance in Arabidopsis thaliana. These studies indicate that SA can protect plants from heat damage during the vegetative and reproductive stage. Therefore, in the present study morphological and biochemical changes in trigenomic Brassica hybrid plants were tested with the exogenously application of SA under heat stress. It was assumed that SA may help in regulation of growth, chlorophyll pigments, and antioxidants activities under heat stress situations in Brassica hybrid.

\section{MATERIALS AND METHODS}

Plant material. The experiment was carried out in the Vegetable Stress Laboratory of Institute of Horticultural Sciences (IHS), University of Agriculture Faisalabad, Pakistan. Hybrids of trigenomic Brassica napus (AACC $\mathrm{x}$ BB) were produced by M.A. Ghani through intra-specific hybridization in the IHS of the University (Abbas, 2018). The hybrids V17 (BB10 x Punjab Canola), V23 (ZY605 x BB15), and V38 (ZS758 x BB10) were sown in plastic pots $(13.2 \mathrm{~cm}$ in diameter and $11 \mathrm{~cm}$ in height) filled with soil and yard compost media with 6:1 ratio, $900 \mathrm{~g}$ per pot. Fifteen days old seedlings were placed under 40 ${ }^{\circ} \mathrm{C}$ for $72 \mathrm{~h}$ for heat stress in a growth chamber where electric appliances were placed to elevate the environment temperature. One set of pots remained at ambient temperature $\left(20-22{ }^{\circ} \mathrm{C}\right)$. Seedlings were sprayed with $0.13 \mathrm{mM}$ salicylic acid prior to expose in high temperature. Salicylic 
acid was sprayed three times and sprayer nozzle was set to discharge only $1 \mathrm{~cm}^{3}$ per spray to the whole plant on both sides of leaves, so that each plant received $3 \mathrm{~cm}^{3}$ of SA solution. The three hybrids were subjected to the following four treatments (with three replications): 1) hybrids under normal condition (control), 2) hybrids under $0.13 \mathrm{mM}$ SA solution, 3) hybrids under heat stress, and 4) hybrids under heat stress and 0.13 mM SA. At start, plants were placed at $25^{\circ} \mathrm{C}$, and later the temperature was increased gradually (2 ${ }^{\circ} \mathrm{C}$ daily, to avoid heat shock) until the desired high temperature was obtained. After heat stress and foliar application of SA, plants were kept at normal temperature $\left(20-22{ }^{\circ} \mathrm{C}\right)$; then, samples were collected after 30 days to assess the different variables.

Morphological variables. Plant height was measured from the tip of the plant to the ground. Plants chosen from each treatment were harvested at the end of the experiment. Leaves and roots were removed from the plants and weighed. Their dry weight was determined after drying in oven at $65^{\circ} \mathrm{C}$ for $72 \mathrm{~h}$.

Measurement of chlorophyll content. A Chlorophyll meter (CCM-200plus Bio-Scientific) was used to determine chlorophyll contents in leaf. Measurements were performed from three leaves of each plant under heat stress as well as in control condition.

Biochemical analysis. Catalase (CAT) activity was measured spectrophotometrically at room temperature by monitoring the decrease in absorbance at $240 \mathrm{~nm}$ resulting from the decomposition of $\mathrm{H}_{2} \mathrm{O}_{2}$. Catalase activity was measured according to the method of Aebi (1983). One unit (U) of catalase activity was defined as the amount of enzyme that caused an absorbance change of 0.001 per min under assay conditions. The reaction mixture contained $100 \mathrm{mM}$ sodium phosphate buffer (pH 7.0), $30 \mathrm{mM} \mathrm{H}_{2} \mathrm{O}_{2}$ and 100 $\mu \mathrm{L}$ of crude extract in a total volume of $3.0 \mathrm{~mL}$.

Peroxidase (POD) activity was determined using 4-methylcatechol as substrate. The increase in the absorption caused by oxidation of 4methylcatechol by $\mathrm{H}_{2} \mathrm{O}_{2}$, was measured at $420 \mathrm{~nm}$ spectrophotometrically. The reaction mixture contained $100 \mathrm{mM}$ sodium phosphate buffer $(\mathrm{pH}$ 7.0), $5 \mathrm{mM}$ 4-methylcatechol, $5 \mathrm{mM} \mathrm{H}_{2} \mathrm{O}_{2}$ and $500 \mu \mathrm{L}$ of crude extract in a total volume of 3.0 $\mathrm{mL}$ at room temperature. One unit of enzyme activity was defined as 0.001 change in absorbance per min, under assay conditions (Onsa et al., 2004).

Superoxide dismutase (SOD) activity was determined by measuring the inhibition in photoreduction of nitroblue tetrazolium (NBT) by SOD enzyme (Kumar et al., 2012). The reaction mixture contained $50 \mathrm{mM}$ sodium phosphate buffer (pH 7.6), $0.1 \mathrm{mM}$ EDTA, $50 \mathrm{mM}$ sodium carbonate, $12 \mathrm{mM}$ L-methionine, $50 \mu \mathrm{M}$ NBT, $10 \mu \mathrm{M}$ riboflavin and $100 \mu \mathrm{L}$ of crude extract in a final volume of $3.0 \mathrm{~mL}$. A control reaction was performed without crude extract. The SOD reaction was carried out by exposing the reaction mixture to white light for $15 \mathrm{~min}$ at room temperature. After 15 min incubation, absorbance was recorded at $560 \mathrm{~nm}$ using a spectrophotometer. One unit (U) of SOD activity was defined as the amount of enzyme causing $50 \%$ inhibition of photochemical reduction of NBT.

Statistical analysis. The results for each variable were compared by analysis of variance and mean separation by Tukey test using the statistical package Statistix 8.1.

\section{RESULTS AND DISCUSSION}

In general, the plant growth characteristics of the three hybrids performed better under SA as compared to the control, and under the combine effect of SA + heat stress as compared to plants exposed to heat stress alone (Table 1). However, except for POD, all variables showed a hybrid $\mathrm{x}$ treatment interaction effect. For instance, a decline in root length was observed in V23 when plants were exposed to heat stress but the effect was not shown in V17 and V38. Root dry weight was increased when SA was applied to plants in V23 and V38, but no effect existed for V17. Also, in this variable, the hybrid V17 showed very low values without differences regardless the treatment applied. Plants of the three hybrids increased their leaf dry weight when they were under heat stress and SA was applied, but the same response did not occur for the root length. A decline in root length was observed in V23 when plants were exposed to heat stress as reported earlier by Hayat et al. (2009) who also found reduced root length under heat stress in the genus Brassica. Additionally, a similar growth 
promoting effect of SA on this genus under heat stress was reported by Cong et al. (2008). The highest values for leaf and root dry weight as well as root length were observed in hybrid V38 under SA application (Table 1). It might be due to SA activates a novel gene BjDREB1B which encodes with DRE (dehydration responsive element) binding protein; this gene has increased the level of proline which in turn improved plant stress tolerance in Brassica (Cong et al., 2008).

Table 1. Effect of salicylic acid (SA, $0.13 \mathrm{mM})$ and heat stress $\left(40{ }^{\circ} \mathrm{C}\right)$ on root length and dry weight, and leaf dry weight in three different hybrids of oilseed rape plants

\begin{tabular}{clccc}
\hline Hybrid & \multicolumn{1}{c}{ Treatment } & $\begin{array}{c}\text { Root length } \\
(\mathrm{cm})\end{array}$ & $\begin{array}{c}\text { Leaf dry weight } \\
(\mathrm{g})\end{array}$ & $\begin{array}{c}\text { Root dry weight } \\
(\mathrm{g})\end{array}$ \\
\hline \multirow{5}{*}{ V17 } & Control & $4.3 \mathrm{~g}$ & $1.23 \mathrm{i}$ & $0.06 \mathrm{e}$ \\
& SA & $5.3 \mathrm{f}$ & $1.43 \mathrm{~h}$ & $0.08 \mathrm{e}$ \\
& Heat stress & $4.3 \mathrm{~g}$ & $0.90 \mathrm{j}$ & $0.05 \mathrm{e}$ \\
& Heat stress+SA & $4.3 \mathrm{~g}$ & $1.21 \mathrm{i}$ & $0.07 \mathrm{e}$ \\
& Control & & & $0.38 \mathrm{c}$ \\
V23 & SA & $6.6 \mathrm{~cd}$ & $2.35 \mathrm{e}$ & $0.45 \mathrm{~b}$ \\
& Heat stress & $7.2 \mathrm{ab}$ & $3.31 \mathrm{~b}$ & $0.31 \mathrm{~d}$ \\
& Heat stress+SA & $5.9 \mathrm{ef}$ & $2.13 \mathrm{~g}$ & $0.35 \mathrm{~cd}$ \\
& Control & $6.4 \mathrm{de}$ & $2.25 \mathrm{f}$ & $0.49 \mathrm{~b}$ \\
& SA & $6.8 \mathrm{bcd}$ & $3.11 \mathrm{c}$ & $0.59 \mathrm{a}$ \\
& Heat stress & $7.4 \mathrm{a}$ & $4.20 \mathrm{a}$ & $0.35 \mathrm{~cd}$ \\
& Heat stress+SA & $6.8 \mathrm{bcd}$ & $2.41 \mathrm{e}$ & $0.44 \mathrm{~b}$ \\
\hline
\end{tabular}

Values that share the same letter within columns are not statistically different from each other according to Tukey's test $(P \leq 0.05)$

The hybrids under heat stress decreased their leaf and root dry weight, although the root length was less affected (Table 1). The application of SA always enhanced significantly $(P \leq 0.05)$ the activities of CAT, SOD and POD, as well as chlorophyll content in the three heat stressed hybrids (Table 2) and allowed the plants to recover the initial growth. This reveals the effect of SA in regulation of growth, chlorophyll content and antioxidant activities of plants under heat stress, which could be associated to mechanisms involved in detoxification of reactive oxygen species.

There was a significant increase in the total chlorophyll content when the treatment of SA was used in all three hybrids. Under heat stress a significant decrease of the chlorophyll content was detected in hybrid V38 with a $22 \%$ reduction (2.18 to $1.70 \mathrm{mg} \cdot \mathrm{g}^{-1}$ ) (Table 2). Lower reductions were also observed in hybrids V17 and V23, but without statistical significance. The three hybrids submitted to heat stress exhibited increase in their chlorophyll content when receiving SA applications. In the present study, it was observed that the brief exposure of plants to high temperature stress reduced plant growth and chlorophyll content. It is well established that photosynthetic pigments such as chlorophyll are sensitive to high-temperature stress (Ghani et al., 2020). Heat stress results in plant leaf pigment loss and consequently significant decrease of photosynthetic activities (Awasthi et al., 2014) Similar decline in chlorophyll content has been observed in turfgrass upon exposure to heat stresses (Jiang and Huang, 2001). Only in V38 there was a significant reduction of chlorophyll content when submitting the control plants to the treatment of heat stress (Table 2).

All the hybrids remained unchanged or showed a slight reduction in CAT activity when exposed to heat stress (Table 2). This effect was in contrast to the findings of He et al. (2005) who observed an increase in the CAT activity under heat stress. The decrease in activity could be due to its nonrobust nature and sensitivity to heat stress, or variation from species to species (Fadzillah et al., 1996). CAT activity reduction has also been observed in heat stressed wheat leaves (Hameed et 
al. 2012) and Kentucky bluegrass (He and Huang, 2010). When SA was applied to control plants or to heat stressed plants the activity of the enzyme increased significantly $(P \leq 0.05)$. The highest increase was observed in the hybrid V17 with a
3.2 fold augment (6.10 to $19.43 \mu \mathrm{mol} \cdot \mathrm{min}^{-1} \cdot \mathrm{mg}^{-1}$ ) compared to the control. When SA was applied to heat stressed plants the increase of CAT was even higher, 4.23 fold augmentation (8.43 to 35.63 $\mu \mathrm{mol} \cdot \mathrm{min}^{1} \cdot \mathrm{mg}^{-1}$ ) as shown in the hybrid V23.

Table 2. Effect of salicylic acid (SA, $0.13 \mathrm{mM})$ and heat stress $\left(40{ }^{\circ} \mathrm{C}\right)$ on chlorophyll content and catalase (CAT) and superoxide dismutase (SOD) activity in three different hybrids of oilseed rape plants

\begin{tabular}{clccc}
\hline Hybrid & \multicolumn{1}{c}{ Treatment } & $\begin{array}{c}\text { Chlorophyll content } \\
\left(\mathrm{mg} \cdot \mathrm{g}^{-1} \mathrm{~F} . \mathrm{W} .\right)\end{array}$ & $\begin{array}{c}\text { CAT } \\
\left(\mathrm{U} \cdot \mathrm{mg}^{-1} \mathrm{protein}\right)\end{array}$ & $\begin{array}{c}\text { SOD } \\
\left(\mathrm{U} \cdot \mathrm{mg}^{-1} \text { protein }\right)\end{array}$ \\
\hline \multirow{5}{*}{ V17 } & Control & $1.18 \mathrm{fg}$ & $6.10 \mathrm{~g}$ & $10.43 \mathrm{~g}$ \\
& SA & $1.90 \mathrm{~cd}$ & $19.43 \mathrm{~cd}$ & $24.80 \mathrm{e}$ \\
& Heat stress & $1.04 \mathrm{~g}$ & $5.50 \mathrm{~g}$ & $19.40 \mathrm{f}$ \\
& Heat stress+SA & $1.52 \mathrm{def}$ & $21.26 \mathrm{~cd}$ & $25.53 \mathrm{e}$ \\
& Control & $1.51 \mathrm{def}$ & $9.66 \mathrm{fg}$ & $21.06 \mathrm{ef}$ \\
V23 & SA & $2.56 \mathrm{ab}$ & $21.86 \mathrm{c}$ & $36.96 \mathrm{~d}$ \\
& Heat stress & $1.45 \mathrm{ef}$ & $8.43 \mathrm{~g}$ & $21.73 \mathrm{ef}$ \\
& Heat stress+SA & $2.29 \mathrm{bc}$ & $35.63 \mathrm{~b}$ & $45.65 \mathrm{c}$ \\
& & & & $40.26 \mathrm{~d}$ \\
V38 & Control & $2.18 \mathrm{bc}$ & $16.70 \mathrm{de}$ & $51.00 \mathrm{~b}$ \\
& SA & $2.80 \mathrm{a}$ & $31.73 \mathrm{~b}$ & $21.93 \mathrm{ef}$ \\
& Heat stress & $1.70 \mathrm{de}$ & $14.26 \mathrm{ef}$ & $75.33 \mathrm{a}$ \\
\hline
\end{tabular}

Values that share the same letter within columns are not statistically different from each other according to Tukey's test $(P \leq 0.05)$

The activity of the superoxide dismutase (SOD) differed among hybrids when they were exposed to heat stress (Table 2). The activity increased in the hybrid V17, declined in V38, and remained constant in V23, compared to the control, showing its genotype dependence. When SA was applied to control or to heat stressed plants the activity of SOD increased significantly $(P \leq 0.05)$, and it differed among hybrids in the magnitude of change. The highest increase was observed in the hybrid V38 with a 3.4 fold augment (21.93 to $75.33 \mathrm{U} \cdot \mathrm{mg}^{-1}$ ) compared to the heat stressed plants. SOD is important in the antioxidant defense system in nearly all living cells exposed to oxygen, and our results are in agreement with the study of Larkindale and Knight (2002) who reported that the application of SA induced maximum protection against heat stress. He et al. (2005) also described the same trend to increase SOD activity after application of SA under heat stress.

The POD activity did not show interaction effect of the factors under study. The control treatment was always lower than the rest of treatments $(P \leq 0.05)$, independently of the hybrid considered (Table 3). This means that application of SA and/or heat stress increased significantly the activity of the enzyme. And, similar to the rest of variables, hybrid V38 always showed the highest and V17 the lowest activity regardless the treatments applied.

The hybrid V17, under heat stress, showed no change in chlorophyll content and CAT, but increase in SOD and POD activities (Table 2). These results are similar to those found by $\mathrm{He}$ and Huang (2010) in a heat-tolerant cultivar of Kentucky bluegrass, which may suggest that the hybrid V17 would present some tolerance to this kind of stress. The hybrid V23 behaved somewhat like V17 except that it did not showed an increase in SOD activity. The hybrid V38 showed decrease in chlorophyll content and in SOD activity, which gives it some characteristics similar to the heatsusceptible Kentucky bluegrass studied by He and Huang (2010). However, V38 was the hybrid that showed the highest overall performance in 
growth, chlorophyll pigments and antioxidant activities in this study.

Semih et al. (2020) found that antioxidants such as CAT and SOD reversed their accumulation and began to decline at very high levels of salinity stress in sorghum, which may indicate that cell damage had reached severe levels and that repair mechanisms might not be enough to overcome the damage to the plant. In our study, heat stress was established at $40{ }^{\circ} \mathrm{C}$, so the limit temperature for the plant to maintain its protective response is still to be clarified.

Table 3. Effect of salicylic acid (SA $0.13 \mathrm{mM}$ ) and heat stress $\left(40{ }^{\circ} \mathrm{C}\right)$ on peroxidase (POD) activity in three different hybrids of oilseed rape plants

\begin{tabular}{|c|c|}
\hline & POD (U. $\mathrm{mg}^{-1}$ protein) \\
\hline Hybrid & \\
\hline V17 & $2.20 \mathrm{c}$ \\
\hline V23 & $4.09 \mathrm{~b}$ \\
\hline V38 & $5.79 \mathrm{a}$ \\
\hline Treatment & \\
\hline Control & $2.82 \mathrm{c}$ \\
\hline SA & $3.96 \mathrm{~b}$ \\
\hline Heat stress & $4.07 \mathrm{~b}$ \\
\hline Heat stress+SA & $5.24 \mathrm{a}$ \\
\hline
\end{tabular}

Values that share the same letter in each factor are not statistically different from each other according to Tukey's test $(P \leq 0.05)$

Higher activity in tolerant genotypes could be responsible for heat stress tolerance as POD is known to decompose $\mathrm{H}_{2} \mathrm{O}_{2}$ and thus prevents lipid peroxidation (Chakraborty and Tongden, 2005). The increase of CAT, SOD and POD in the three canola hybrids when adding SA to the heat stressed plants is similar to that shown by rice seedlings when adding silicon to arsenic stressed plants (Boorboori et al., 2020).

In general, the use of SA showed a significant relieve of canola plants submitted to heat stress, and the response was associated to elevated activity of antioxidative enzymes which seems to produce thermotolerance allowing the plants to resist high temperatures.

\section{CONCLUSION}

In general, morphological traits, chlorophyll, and biochemical activities were reduced in tri- genomic Brassica hybrids exposed to high temperature stress. Application of salicylic acid always increased those values and was helpful in mitigating the detrimental effect of the heat stress by enhancing the activity of antioxidative enzymes.

\section{ACKNOWLEDGEMENT}

Authors are thankful to Higher Education Commission, Pakistan (HEC) for the facilities and encouragement. This work was also supported by Startup Project (HEC) by which they provided us funding for germplasm collection and hybrid production.

\section{LITERATURE CITED}

1. Abbas, M.M. 2018. $F_{1}$ seed production of trigenomic by interspecific crossing between Brassica napus and Brassica nigra. MSc Thesis, Institute of Horticultural Sciences, University of Agriculture Faisalabad, Pakistan. $132 \mathrm{p}$.

2. Aebi, H.E. 1983. Catalase. In: H.U. Bergmeyer (ed.). Methods of Enzymatic Analysis, Verlag Chemie, Weinhem. pp. 273-286.

3. Angadi, S.V., H.W. Cutforth, P.R. Miller, B.G. McConkey, M.H. Entz, S.A. Brandt and K.M. Volkmar. 2000. Response of three Brassica species to high temperature stress during reproductive growth. Sci. 35: 8693-701.

4. Awasthi, R., N. Kaushal, V. Vadez, N.C. Turner, J. Berger, K.H. Siddique and H. Nayyar. 2014. Individual and combined effects of transient drought and heat stress on carbon assimilation and seed filling in chickpea. Funct. Plant Biol. 41: 1148-1167.

5. Boorboori, M.R., W. Lin, W. Zhan and C. Fang. 2020. The role of silicon to increase arsenic tolerance in rice (Oryza sativa L.) seedlings by reinforcing anti-oxidative defense. Bioagro 32(3): 159-168.

6. Carlson, R.E. 1990. Heat stress, plant-available soil moisture, and corn yields in Iowa: a shortand long-term view. Journal of Production Agriculture 3: 293-297.

7. Chakrabarti, N. and S. Mukherjee. 2003. Effects of phytohormones pretreatment of nitrogen metabolism in Vigna radiata under salt stress. Bio. Plant. 36: 63-66. 
8. Chakraborty, U. and C. Tongden. 2005. Evaluation of heat acclimation and salicylic acid treatments as potent inducers of thermo tolerance in Cicer arietinum L. Curr. Sci. 89: 384-389.

9. Clarke, S.M., S.M. Cristescu, O. Miersch, F.J. Harren, C. Wasternack and L.A. Mur. 2009. Jasmonates act with salicylic acid to confer basal thermotolerance in Arabidopsis thaliana. New Phytol. 182: 175-87.

10.Cong L, T.Y. Chai and X.Y. Zhang. 2008. Characterization of the novel gene BjDREB1B encoding DRE-binding transcription factor from Brassica juncea L. Biochem, Biophys. Res. 371: 702-706.

11.Fadzillah, N.M., V. Gill, R.P. Finch and R.H. Burdon. 1996. Chilling, Oxidative stress and antioxidant responses in shoot cultures of rice. Planta 199: 552-556.

12.Fuentes, F. and A. Bhargava. 2011. Morphological analysis of quinoa germplasm grown under lowland desert conditions. Journal of Agronomy and Crop Science 197: 124-134.

13.Ghani, M.A., M.M. Abbas, M. Amjad, K. Ziaf, B. Ali, T. Shaheen et al. 2020. Production and characterization of tomato derived from interspecific hybridization between cultivated tomato and its wild relatives. The Journal of Horticultural Science and Biotechnology 95(4): 506-520.

14.Hameed, A, M. Goher and I. Iqbal. 2012. Heat stress-induced cell death, changes in antioxidants, lipid peroxidation, and protease activity in wheat leaves. J. Plant Growth Regul. 31: 283-291.

15.Hayat, S. and A. Ahmad. 2007. Salicylic Acid: A Plant Hormone. Springer. Dordrecht, The Netherlands.

16. Hayat, S., A. Masood, M. Yusuf, Q. Fariduddin and A. Ahmad. 2009. Growth of Indian mustard (Brassica juncea L.) in response to salicylic acid under hightemperature stress. Brazilian Journal of Plant Physiology 21(3): 187-195.

17.He, Y. and B. Huang. 2010. Differential responses to heat stress in activities and isozymes of four antioxidant enzymes for two cultivars of Kentucky bluegrass contrasting in heat tolerance. J. Amer. Soc. Hort. Sci. 135: 116-124.

18.He, Y.L., Y.L. Liu, W.X. Cao, M.F. Huai, B.G. $\mathrm{Xu}$ and B.G. Huang. 2005. Effect of salicylic acid on heat tolerance associated with antioxidant metabolism in Kentucky bluegrass. Crop Sci. 45: 988-995.

19.IPCC 2014. Climate Change 2014-Impacts, adaptation, and vulnerability: Regional Aspects. Cambridge, UK: Cambridge University Press, pp. 688.

20.Jiang, Y. and B. Huang. 2001. Drought and heat stress injury to two cool season turfgrasses in relation to antioxidant metabolism and lipid peroxidation. Crop Sci. 41: 436-442.

21.Knight, H. and M.R. Knight. 2001. Abiotic Stress signalling pathways: Specificity and cross-talk. Trends Plant Sci. 6: 262-267.

22.Kubo, A., M. Aono, N. Nakajima, Saji, K. Tanaka and N. Kondo. 1999. Differential responses in activity of antioxidant enzymes to different environmental stresses in Arabidopsis thaliana. J. Plant Res. 127: 279-290.

23.Kumar, A., S. Dutt, G. Bagler, P.S. Ahuja, and S. Kumar. 2012. Engineering a thermo-stable superoxide dismutase functional at subzero to $50{ }^{\circ} \mathrm{C}$, which also tolerates autoclaving. Scientific Reports 2: 387.

24.Larkindale, J. and M. R. Knight. 2002. Protection against heat stress-induced oxidative damage in Arabidopsis involves calcium, abscisic acid, ethylene and salicylic acid. Plant Physiol. 128: 682-695.

25.Lesjak, J. and D.F. Calderini. 2017. Increased night temperature negatively affects grain yield, biomass and grain number in Chilean quinoa. Frontiers in Plant Science 8: 352.

26.Mizanur, R., S. Mamidi and M. Rahman. 2018. Genome-wide association study of heat stress tolerance traits in spring-type Brassica napus L. under controlled conditions. The Crop Journal 6: 115-125.

27.Momoh, E.J., W.J. Zhou and V. Kristiansson. 2002. Variation in the development of secondary dormancy in oilseed rape genotypes under conditions of stress. Weed. Res. 42: 446455. 
28.Onsa, G., N. Saari, J. Selamat and J. Bakar. 2004. Purification and characterization of membrane-bound peroxidases from metroxylon sagu. Food Chemistry 85: 365-376.

29. Prasad, P.V., R. Bheemanahalli, and S.V. Jagadish. 2017. Field crops and the fear of heat stress-opportunities, challenges and future directions. Field Crops Research 200: 114121.

30.Porter, J.R. 2005. Rising temperatures are likely to reduce crop yields. Nature 436: 174 .

31.Sairam. R.K. and A. Tyagi. 2004. Physiological and molecular biology of salinity stress tolerance in plants. Curr. Sci. 86: 407421.

32. Sato, S, M.M. Peet and J.F. Thomas. 2002. Determining critical pre- and post-anthesis periods and physiological processes in Lycopersicon esculentum Mill., exposed to moderately elevated temperatures. J. Exp. Bot. 53(371): 1187-1195.

33.Semih, Y., R. Temizgül, C. Yürürdurmaz and
M. Kaplan. 2020. Oxidant and antioxidant enzyme response of Redbine sweet sorghum under $\mathrm{NaCl}$ salinity stress. Bioagro 32(1): 3138.

34.Senaratna, T., D. Touchell, E. Bunn and K. Dixon. 2000. Acetyl salicylic acid (aspirin) and salicylic acid induce multiple stress tolerance in bean and tomato plants. Plant Growth Regul. 30: 157-161.

35.Wahid, A., S. Gelani, M. Ashraf, and M.R. Foolad. 2007. Heat tolerance in plant: An overview. Environ. Exp. Bot. 61: 199-223.

36.Young, L.W., R.W. Wilen and P.C. BonhamSmith. 2004. High temperature stress of Brassica napus during flowering reduces micro and megagametophyte, fertility, induces fruit abortion and disrupts seed production. J. Exp. Bot. 55: 485-95.

37.Zhou, W.J. 2001. Oilseed rape. In: G.P. Zhang and W.J. Zhou (eds.). Crop Production. Zhejiang University Press, Hangzhou, China. pp. 153-178. 